\title{
Evaluation of four rhizobacteria on tomato growth and suppression of root-knot nematode, Meloidogyne javanica under greenhouse conditions, a pilot study
}

\author{
Fatemeh Sohrabi ${ }^{1}$, Mahyar Sheikholeslami ${ }^{2 *}$, Ramin Heydari ${ }^{3}$, Saeed Rezaee ${ }^{1}$ and Rouhallah Sharifi ${ }^{4}$
}

\begin{abstract}
Growth-promoting rhizobacteria are free-living bacteria that colonize the roots and stimulate the plant growth. Many of these bacteria secrete a range of extracellular metabolites that can be involved in the biological control of plant pathogens. In this study, the effect of four plant growth-promoting rhizobacteria (PGPR) was evaluated on tomato growth parameters as well as biological control of the root-knot nematode (RKN) (Meloidogyne javanica). Tomato seedlings were inoculated with four isolates of PGPR including Pseudomonas fluorescens, Pseudomonas striata, Bacillus subtilis, and Paenibacillus polymyxa and cultivated in the presence or absence of RKN. The results showed that the PGPR significantly increased the plant growth parameters. Bacterial strains also significantly affected the reproductive factor of Meloidogyne javanica significantly so that $P$. fluorescens and $B$. subtilis reduced the reproductive factor from 112.15 to 24.94 and 24.96, respectively. Based on these results, among applied rhizobacteria in this study, P. polymyxa can be regarded as the best candidate for promoting the growth and biological control of $M$. javanica in tomato crop under greenhouse conditions.
\end{abstract}

Keywords: Biological control, Meloidogyne javanica, Plant growth-promoting rhizobacteria, Tomato

\section{Background}

Tomato (Solanum lycopersicum L.) is an important crop in the world due to the diverse uses and high nutritional value of the fruit. In Iran, various species of root-knot nematode (RKN) have been reported from different crops including tomato, but the most prevalent one is Meloidogyne javanica (Damadzadeh 2007). Various microorganisms attack Meloidogyne spp. in soil and reduce their population of which the fungi, bacteria, and nematodes are the most important ones (Stirling 1991). A group of microorganisms that has been considered to improve plant growth and controlling RKNs are the plant growth-promoting rhizobacteria (PGPR) (Weller et al. 2002 and Lucy et al. 2004). Pseudomonas spp. are aerobic, Gram-negative bacteria, ubiquitous in agricultural soils, and are well adapted to grow in the rhizosphere (Weller 2007). Bacillus spp. have also an

\footnotetext{
* Correspondence: m1sheikh@yahoo.com

${ }^{2}$ Department of Plant Protection, Agricultural and Natural Resources Research Center, Kermanshah, Iran

Full list of author information is available at the end of the article
}

outstanding function in controlling plant pathogens and increasing plant growth parameters. Likewise other characteristics such as production of secondary metabolites, especially antibiotics, high tolerance to temperature alternations in the environment, rapid growth in vitro, and production of persistent endospores in the soil make Bacillus spp. as an appropriate option in controlling plant diseases (Backman et al. 1997). Bacillus thuringiensis decreased the populations of some important nematodes like Globodera pallida, M. javanica, and Meloidogyne incognita at remarkable levels (Racke and Sikora 1992 and Zukerman et al. 1993). Bacillus pumilus and Bacillus mycoides were the most effective bacteria in reducing the number of galls and egg masses of $M$. incognita by 33 and 39\%; respectively (Mekete et al. 2009). PGPR exploit various mechanisms in suppression of RKNs. Pseudomonas aeruginosa could suppress the nematode activity by secretion of the enzymes proteinase and glycoproteinase (Ali et al. 2002). Bacillus cereus could decrease egg hatching of M. incognita up to 90\% (Nagesh et al. 2005). Crude extracellular protein 
extract from culture supernatant of Brevibacillus laterosporus killed the nematode Panagrellus redivivus within $72 \mathrm{~h}$ (Huang et al. 2005). Culture filtrates of five isolates of Pseudomonas fluorescens and one isolate of each species of Pseudomonas putida, Bacillus subtilis, Brevibacillus brevis, and Serratia sp. caused 35-38\% reduction in egg hatching and $32.2-48.8 \%$ increase in the mortality rate of juvenile two $\left(\mathrm{J}_{2}\right)$ larvae of M. incognita (Behzadi Amin et al. 2014).

The objective of this research was to study the effect of four PGPR strains on plant growth parameters and on suppression of RKN (M. javanica) infecting tomato plants under greenhouse conditions.

\section{Material and methods}

\section{Detection and preparation of nematode inoculum}

In order to prepare the nematode isolate, a number of soil and root samples were collected from an infected tomato field in Kermanshah province, Iran. Single egg masses of root galls were picked up from well-washed infected tomato root and placed near 4-leaved tomato seedlings of the cultivar Early Urbana Y. These inoculated seedlings were maintained under favorable greenhouse conditions at $18-32{ }^{\circ} \mathrm{C}$ for 60 days to replicate nematodes. Identification of the pure population of Meloidogyne species was performed according to Taylor and Netscher (1974). Extraction of nematode from infected tissues for the experiments was performed according to Hussey and Janssen (2002) method.

\section{Preparation of PGPR inoculum}

Three strains of PGPR were received from Agrilife Biofertilizer Manufacturer, India, including Paenibacillus polymyxa (Prazmowski) Ash et al. (NCIM 2188), Bacillus subtilis (Ehrenberg) Cohn (MCC 0067), and Pseudomonas striata Chester (NCIM 2847). P. fluorescens (Flugge) Migula (333-S) strain was received from the Dep. of Plant Protection, College of Agriculture, University of Tehran, Karaj, Iran. Inocula of bacterial strains were prepared in Nutrient Broth (Quelab, Canada) on a shaker at $120 \mathrm{rpm}$ for $48 \mathrm{~h}$ at 28-30 ${ }^{\circ} \mathrm{C}$. Population density of the PGPR strains was measured with serial dilution method (Liddell and Parke 1989). Every PGPR strain had at least $10^{8} \mathrm{CFU} / \mathrm{ml}$.

\section{Effect of PGPR strains on plant growth parameters and on suppression of RKN}

A factorial experiment was performed with 10 treatments and 4 replications in a completely randomized design. Bacterial factor had 5 levels (without bacteria, $P$. fluorescens, Paenibacillus polymyxa, P. striata, and B. subtilis), and RKN factor had 2 levels (zero population and 5000 eggs and larvae per kilogram of soil). Tomato seeds, cv. Falat, were sown in a pasteurized soil bed. Three weeks after cultivation, 4-leaved seedlings were transferred to the

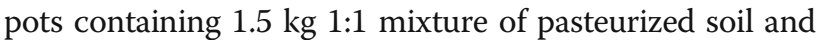

sand. Before planting, every seedling was inoculated by $1 \mathrm{ml}$ of $10^{8} \mathrm{CFU} / \mathrm{ml}$ suspension of each bacterium. After transplanting, 5000 eggs and $J_{2}$ larvae of $M$. javanica were added to every treatment (Hussey and Barker 1973). The pots were maintained at $18-32{ }^{\circ} \mathrm{C}$ and $16: 8$ day/night photoperiod for 60 days. To provide nutrients, the pots were irrigated with Hoagland solution every 2 weeks. At the end of the experiment, plant growth parameters including shoot height, root length, fresh and dried weight of shoot, and root and several indices related to nematode including mean number of galls and egg masses in the plant root, number of eggs in egg mass, and number of $\mathrm{J}_{2}$ larvae in soil were measured. The data were analyzed by SAS 9.4 software. Mean comparison of all factors were performed by least significant difference (LSD) at \%1 probability level.

\section{Results and discussion Identification of the RKN}

According to the cuticular perennial pattern of the female nematode body and morphological and morphometric detections of females and $J_{2}$ larvae, the nematode species was confirmed as M. javanica (Hartman and Sasser 1985).

\section{Impact of PGPR on plant growth parameters}

The results of this research showed that applied PGPR not only promoted the plant growth parameters but also reduced the damage caused by $M$. javanica, which is in coordination with previous studies (Tian et al. 2007; Chauhan et al. 2015 and Amani Beni et al. 2016). However, there were insignificant differences among the bacterial treatments. The plants inoculated solely by $M$. javanica had the lowest shoot height. In the study performed by Moustaine et al. (2017), inoculation of several PGPR bacterial strains revealed the stimulatory effect of bacteria belonging to the genus Bacillus on the stem height and collar diameter of tomato plants. Root length data showed that PGPR improved root length either alone or in combination with nematode; however, there was insignificant difference among the four PGPR strains. Results of aerial parts fresh weight measurements indicated that $P$. fluorescens, P. polymyxa, and B. subtilis enhanced the shoot fresh weight in contrast to control significantly. The presence of PGPR in the treatments inoculated by both bacteria and nematode could minimize the reduction of the fresh weight of aerial parts, which in this sense, $B$. subtilis and $P$. polymyxa had the most effect in reduction of nematode damage and as a result increasing the fresh weight of aerial parts in these treatments. In the present study, $P$. striata increased the plant growth parameters and decreased the growth and development indices of the RKN, but compared to other treatments subjected to PGPR, the least effect was observed on plant growth and nematode damage reduction. In an experiment, seed inoculation of 
pearl millet [Pennisetum glaucum (L.) R. Br.] with P. striata improved the root and shoot biomasses and higher $\mathrm{P}$ uptake by straw and grain (Gaind 2013). Similarly combined application of Bradyrhizobium sp. with P. striata increased nodule occupancy in soybean resulting in more biological $\mathrm{N}_{2}$ fixation (Dubey 1996).

Comparison of the means of shoot dry weight revealed a significant difference between the healthy control, and the treatments inoculated by PGPR. B. subtilis and $P$. fluorescens had more effect to increase shoot dry weight.

Results of measuring root fresh weight indicated that this parameter in PGPR inoculated plants had a significant difference with healthy control ones. The treatment inoculated with $P$. polymyxa had the most effect to increase the root fresh weight, so that $P$. polymyxa increased this parameter by $69 \%$ compared to control (without nematodes and bacteria). Interestingly, root fresh weight in infected control was significantly more than healthy control treatment, which it can be due to the gall formation in this treatment. The treatment inoculated by nematode in the presence of the bacteria compared to infected control exhibited reduction of root fresh weight and showed the advantageous function of PGPR to increase the plant growth parameters and reduction of gall numbers and as a result reduction of nematode damage. However, treatment inoculated by $P$. polymyxa and $M$. javanica demonstrated an increase of the root fresh weight compared to infected control. It revealed the positive effect of $P$. polymyxa to increase root fresh weight in addition to decrease gall formation (Table 1). In this regard, root growth was stimulated very significantly by Bacillus spp. in comparison with other strains and compared to the control (Moustaine et al. 2017). Variance data analysis of root dry weight indicated significant difference between the inoculated plants with PGPR and control plants (without nematode and bacteria). Nevertheless, this difference was not observed in the treatment inoculated with P. striata. P. fluorescens had the highest and $P$. striata had the lowest percentage of increase in mean dry root weight with 69 and 35\%, respectively, than the control treatment. Based on the root dry weight parameter, $P$. fluorescens had the most effect to reduce the nematode damage and also to increase root dry weight (Table 1). PGPR have this ability to improve plant growth either through direct effect through synthesis of phytohormones (Xie et al. 1996) or by decreasing the effect of pathogens (Weller et al. 2002).

\section{Impact of PGPR to reduce the nematode contamination of tomato plants}

Obtained results showed that PGPR had significant effect on reducing nematode growth and development indices including gall number, egg mass, egg number in each egg mass, reproduction factor, and $\mathrm{J}_{2}$ larvae number. In the treatment, solely inoculated by $M$. javanica, almost $27 \mathrm{gal} / \mathrm{g}$ of root and $29.75 \mathrm{egg}$ mass/g of root were produced. On the other hand, all four bacterial strains significantly reduced these parameters. The lowest gall number, $13.75 \mathrm{gal} / \mathrm{g}$ of root, was recorded in the plants treated with P. fluorescens, while the lowest number of egg mass was achieved in $P$. polymyxa treated plants. In these conditions, $P$. fluorescens reduced the gall number by $49 \%$ and $P$. polymyxa reduced the number of eggs per $1 \mathrm{~g}$ of root by $50 \%$ compared to the nematode alone control treatment. Plants treated with $P$. polymyxa had also the least egg number inside every egg mass as low as half of the infected RKN inoculated control (Table 2). In the study performed by Khan et al. (2008), application of various concentrations of culture filtrate or bacterial suspension

Table 1 Mean comparison of tomato growth parameters in treatments inoculated with plant growth parameters promoting rhizobacteria, P. fluorescens, P. polymyxa, P. striata, B. subtilis and root-knot nematode, and M. javanica under greenhouse conditions

\begin{tabular}{|c|c|c|c|c|c|c|}
\hline Treatment & Shoot length $(\mathrm{cm})$ & Shoot fresh weight (g) & Shoot dry weight (g) & Root length $(\mathrm{cm})$ & Root fresh weight (g) & Root dry weight (g) \\
\hline Control & $78.50 \mathrm{bc}$ & $61.50 \mathrm{bc}$ & $15.00 \mathrm{bc}$ & $21.00 \mathrm{a}$ & $29.25 \mathrm{e}$ & $9.25 \mathrm{~d}$ \\
\hline P. fluorescens & $99.50 \mathrm{a}$ & $82.25 \mathrm{a}$ & $21.00 \mathrm{a}$ & $24.50 \mathrm{a}$ & $58.25 \mathrm{~cd}$ & $24.00 \mathrm{a}$ \\
\hline P.striata & $94.75 a b$ & $73.00 \mathrm{ab}$ & $16.75 \mathrm{ab}$ & $22.00 \mathrm{a}$ & $54.50 \mathrm{~cd}$ & $14.25 \mathrm{~cd}$ \\
\hline B. subtilis & $98.00 \mathrm{a}$ & $83.00 \mathrm{a}$ & $21.00 \mathrm{a}$ & $24.00 \mathrm{a}$ & $68.75 \mathrm{bc}$ & $22.50 \mathrm{a}$ \\
\hline P. polymyxa & $100.25 \mathrm{a}$ & $83.50 \mathrm{a}$ & $20.75 a b$ & $24.50 \mathrm{a}$ & $97.00 \mathrm{a}$ & $23.00 \mathrm{a}$ \\
\hline $\begin{array}{l}\text { P. fluorescens }+M \text {. } \\
\text { javanica }\end{array}$ & $91.00 \mathrm{ab}$ & $71.00 a b$ & $19.25 a b$ & $20.00 \mathrm{a}$ & $58.75 \mathrm{~cd}$ & $23.25 \mathrm{a}$ \\
\hline $\begin{array}{l}P \text {. striata }+M \text {. } \\
\text { javanica }\end{array}$ & $71.00 \mathrm{~cd}$ & $57.00 \mathrm{c}$ & $16.00 \mathrm{abc}$ & $19.50 \mathrm{a}$ & $45.25 d$ & $16.00 \mathrm{bc}$ \\
\hline $\begin{array}{l}\text { B. subtilis + M. } \\
\text { javanica }\end{array}$ & $93.50 \mathrm{ab}$ & $78.50 \mathrm{a}$ & $19.00 \mathrm{ab}$ & $19.00 \mathrm{a}$ & $62.25 \mathrm{bc}$ & $22.00 \mathrm{a}$ \\
\hline $\begin{array}{l}\text { P. polymyxa }+M \text {. } \\
\text { javanica }\end{array}$ & $92.00 \mathrm{ab}$ & $76.00 \mathrm{a}$ & $19.25 a b$ & $20.25 \mathrm{a}$ & $77.00 \mathrm{~b}$ & $22.75 a$ \\
\hline M. javanica & $61.00 \mathrm{~d}$ & $42.50 \mathrm{~d}$ & $10.25 c$ & $11.00 \mathrm{~b}$ & $69.00 \mathrm{bc}$ & $20.25 a b c$ \\
\hline
\end{tabular}

Values followed by the same letter in the same column are not significantly different using LSD test $(P \leq 0.01, n=4)$ 
Table 2 Mean comparison of growth and developmental parameters of M. javanica on tomato plants inoculated and non-inoculated with plant growth promoting Rhizobacteria, P. fluorescens, P. polymyxa, P. striata, and B. subtilis under greenhouse conditions

\begin{tabular}{llllll}
\hline Treatment & No. galls/1 g root & No. egg masses/1 g root & No. eggs/egg mass & No. J2 /100 g soil & Reproductive factor (RF) \\
\hline M. javanica & $27.25 \mathrm{a}$ & $29.75 \mathrm{a}$ & $260.00 \mathrm{a}$ & $268.00 \mathrm{a}$ & $112.15 \mathrm{a}$ \\
P. fluorescens + M. javanica & $13.75 \mathrm{~b}$ & $15.75 \mathrm{~b}$ & $131.00 \mathrm{bc}$ & $136.00 \mathrm{~b}$ & $24.94 \mathrm{~b}$ \\
P. striata + M. javanica & $16.25 \mathrm{~b}$ & $18.00 \mathrm{~b}$ & $201.00 \mathrm{ab}$ & $153.00 \mathrm{~b}$ & $33.20 \mathrm{~b}$ \\
B. subtilis + M. javanica & $14.50 \mathrm{~b}$ & $15.25 \mathrm{~b}$ & $128.00 \mathrm{bc}$ & $129.50 \mathrm{~b}$ & $24.69 \mathrm{~b}$ \\
P. polymyxa + M. javanica & $14.50 \mathrm{~b}$ & $14.75 \mathrm{~b}$ & $123.50 \mathrm{c}$ & $129.50 \mathrm{~b}$ & $28.51 \mathrm{~b}$ \\
\hline
\end{tabular}

RF: the ratio of the final population to the primary population of the nematode $R f=\frac{P f}{P i}$

Values followed by the same letter in the same column are not significantly different using LSD test $(P \leq 0.01, n=4)$

of P. polymyxa GBR-1 into potting soil infected with $M$. incognita, reduced the root galling and nematode populations, and also increased tomato plant growth parameters and root-mass production compared with the untreated control. Similarly $P$. polymyxa strain GBR-1 reduced egg hatching and population of $M$. incognita (Khan et al. 2008). Based on a study performed by Cetintas et al. (2018) among 15 bacterial strains studied, 2 strains of Paenibacillus castaneae and 2 strains of Mycobacterium immunogenum were identified as the best promising biocontrol agents for the management of $M$. incognita. Prevention of egg hatching is one of the mechanisms to emerge resistance against RKNs by plant growth-promoting bacteria. One of the reasons for decreasing the number of galls in the plants both inoculated by bacteria and nematodes could be due to the lack of hatching eggs. This reduction, in turn, may arise from the stimulation of plant defense systems and the production of plant chitinases (Seenivasan et al. 2012). While the formation of chitin layers in nematode eggs requires development, the chitinases can disrupt this process and prevent the egg hatching.

In this study, the mean number of $\mathrm{J}_{2}$ populations in the PGPR inoculated treatments was significantly lower than that of the infected control. Both of bacterial strains $P$. polymyxa and B. subtilis reduced $\mathrm{J}_{2}$ population to 129.5 comparing to 268 in infected control, which was equal to (51\%) reduction of $\mathrm{J}_{2} \mathrm{~s}$ in these two treatments (Table 2). PGPR exploit several mechanisms in suppression of plant pathogenic nematodes. Tian et al. (2007) showed that removal of alkaline protease BLG4 in Bacillus laterosporus resulted in destruction of $57 \%$ nematicidal activity of this bacterium. A neutral protease (npr) (designated Bae16) toxic to nematodes, which was purified from Bacillus nematocida could destroy the nematode cuticle and its hydrolytic substrates included gelatin and collagen (Niu et al. 2006).

Bacterial strains also significantly affected the reproductive factor of $M$. javanica, so that $P$. fluorescens and B. subtilis reduced the reproductive factor from 112.15 to 24.94 and 24.96 , respectively (Table 2 ).

\section{Conclusions}

According to the results of this study, PGPR can be suitable candidates for use in biological control of $M$. javanica, which, in turns, will be an effective action to reduce the consumption of pesticides and helping to develop safer sustainable agriculture.

\section{Acknowledgements \\ The authors are grateful to the Agricultural and Natural Resources Research Center of Kermanshah, Iran, for the facilities provided for conducting the study.}

\section{Availability of data and materials}

The data and material are included in the dissertation of the first author but has not yet been published formally.

\section{Authors' contributions}

First and second authors, FS and MSH are responsible for conducting the experimental work. Second author MSH is responsible for designing and supervising the study, revising the paper scientifically, and checking analysis and interpretation of data. Third author, $\mathrm{RH}$ is responsible for supervising the study. Fourth and fifth authors, SR and RSH are responsible for the general cooperation and contribution to the study. All authors read and approved the final manuscript.

\section{Ethics approval and consent to participate}

Not applicable.

\section{Consent for publication}

Not applicable.

\section{Competing interests}

The authors declare that they have no competing interests.

\section{Publisher's Note}

Springer Nature remains neutral with regard to jurisdictional claims in published maps and institutional affiliations.

\section{Author details}

${ }^{1}$ Department of Plant Pathology, College of Agriculture and Natural Resources, Science and Research Branch, Islamic Azad university, Tehran, Iran. ${ }^{2}$ Department of Plant Protection, Agricultural and Natural Resources Research Center, Kermanshah, Iran. ${ }^{3}$ Department of Plant Protection, College of Agriculture and Natural Resources, University of Tehran, Karaj, Iran. ${ }^{4}$ Department of Plant Protection, College of Agriculture and Natural Resources, University of Razi, Kermanshah, Iran.

Received: 25 March 2018 Accepted: 27 June 2018

Published online: 13 July 2018

\section{References}

Ali NI, Siddiqui IA, Shaukat SS, Zaki MJ (2002) Nematicidal activity of some strains of Pseudomonas spp. Soil Biol Biochem 34:1051-1058 
Amani Beni F, Karegar A, Taghavi SM (2016) Effect of Pseudomonas fluorescens $\mathrm{CHAO}$ and green manures of some inhibitory plants on activity of the rootknot nematode, Meloidogyne incognita and infected tomato growth parameters. Iran J Plant pathol 59(3):339-356

Backman PA, Wilson M, Murphy JF (1997) Bacteria for biological control of plant diseases. In: Rechcigl NA, Rechcigl JE (eds) Environmentally safe approaches to crop disease control. CRC Lewis Publishers, Boca Raton, pp 95-109

Behzadi Amin R, Kargar Bideh A, Taghavi SM (2014) Evaluation of rhizobacteria effects on the activity of root-knot nematode, Meloidogyne incognita under greenhouse and laboratory conditions. Iran J Plant Pathol 50(1):53-68

Cetintas R, Kusek M, Ameen Fateh S (2018) Effect of some plant growthpromoting rhizobacteria strains on root-knot nematode, Meloidogyne incognita, on tomatoes. Egypt J Biol Pest Co 28:7

Chauhan H, Bagyaraja DJ, Selvakumarb G, Sundaram SP (2015) Novel plant growth promoting rhizobacteria, prospects and potential. Appl Soil Ecol 95:38-53

Damadzadeh M (2007) Agricultural nematology. Andisheh-gostar publisher, Isfahan, Iran, p 208 (in Persian)

Dubey SK (1996) Combined effect of Bradyrhizobium japonicum and phosphatesolubilizing Pseudomonas striata on nodulation, yield attributes and yield of rain fed soybean (Glycine max) under different sources of phosphorus in Vertisols. Indian J Agric Sci 66(1):28-32

Gaind S (2013) Pseudomonas striata for improving phosphorus availability in soil under pearl millet cultivation. J Crop Improv 27(3):255-271

Hartman KM, Sasser JN (1985). Identification of Meloidogyne species on the basis of differential host test and perineal pattern morphology. In: advanced treatise on Meloidogyne Vol. 2. Raleigh NC. North Carolina State University pp 69-77

Huang X, Tian B, Niu Q, Yang J, Zhang L, Zhang K (2005) An extracellular protease from Brevibacillus laterosporus G4 without parasporal crystal serve as pathogenic factor in the infection against nematodes. Res Microbiol 156:719-727

Hussey RS, Barker KR (1973) A comparison of methods of collecting inocula of Meloidogyne spp., including a new technique. Plant Dis Rep 57:1025-1028

Hussey RS, Janssen GSW (2002) Root-knot nematodes: Meloidogyne species. In: Starr JL, Cook R, Brige J (eds) Plant Resistance to parasitic Nematodes. CABI, In, pp 69-77

Khan Z, Kim SG, Jeon YH, Khan HU, Son SH, Kim YH (2008) A plant growth promoting rhizobacterium, Paenibacillus polymyxa strain GBR-1, suppresses root-knot nematode. Bioresour Technol 99:3016-3023

Liddell C, Parke J (1989) Enhanced colonization of pea taproots by a fluorescent pseudomonad biocontrol agent by water infiltration into soil. Phytopathology 79:1327-1332

Lucy M, Reed E, Glick BR (2004) Application of free living plant growthpromoting rhizobacteria. Antonie Leeuwenhoek 86:1-25

Mekete T, hallman J, Kiewnick S, Sikora R (2009) Endophytic bacteria from Ethiopian coffee plants and their potential to antagonize Meloidogyne incognita. Nematology 11(1):117-127

Moustaine M, Elkahkahi R, Benbouazza A, Benkirane R, Achbani EH (2017) Effect of plant growth promoting rhizobacterial (PGPR) inoculation on growth in tomato (Solanum lycopersicum L.) and characterization for direct PGP abilities in Morocco. Int J Environ Agric Biotechnol 2(2):590-596

Nagesh M, Asokan R, Mohan KS (2005) Partial characterization of novel nematicidal toxins from Bacillus cereus Frankland 1887 and their effect on root-knot nematode, Meloidogyne incognita ( Kofoid \& White) Chitwood. J Biol Control 19(1):65-69

Niu Q, Huang X, Zhang L, Li Y, Li J, Yang J, Zhang K (2006) A neutral protease from Bacillus nematocida, another potential virulence factor in the infection against nematodes. Arch Microbiol 185:439-448

Racke J, Sikora RA (1992) Isolation, formulation and antagonistic activity of rhizobacteria toward the potato cyst nematode Globodera pallida. Soil Biol Biochem 24:521-526

Seenivasan N, David PMM, Vivekanandan P, Samiyappan R (2012) Biological control of rice root-knot nematode, Meloidogyne graminicola through mixture of Pseudomonas fluorescens strains. Biocontrol Sci Tech 22(6):611-632

Stirling GR (1991) Biological control of plant parasitic nematode: progress, problems and prospects. CAB International, Wallingford

Taylor DP, Netscher C (1974) An improved technique for preparing perineal patterns of Meloidogyne spp. Nematologica 20:268-269

Tian B, Yang J, Zhang KQ (2007) Bacteria used in the biological control of plantparasitic nematodes: populations, mechanisms of action, and future prospects. FEMS Microbiol Ecol 61:197-213
Weller DM (2007) Pseudomonas biocontrol agents of soilborne pathogens: looking back over 30 years. Phtopathology 97(2):250-256

Weller DM, Raaijmakers JM, McSpadden Gardener BB, Thomashow LS (2002) Microbial populations responsible for specific suppression to plant pathogens. Annu Rev Phytopathol 40:309-348

Xie H, Pasternak JJ, Glick BR (1996) Isolation and characterization of mutants of the plant growth-promoting rhizobacterium Pseudomonas putida GR12-2 that overproduce indole acetic acid. Curr Microbiol 32:67-71

Zukerman BM, Dicklow MB, Acosta N (1993) A strain of Bacillus thuringiensis for the control of plant-parasitic nematodes. Biocontrol Sci Tech 3(1):41-46

\section{Submit your manuscript to a SpringerOpen ${ }^{\circ}$ journal and benefit from:}

- Convenient online submission

- Rigorous peer review

- Open access: articles freely available online

- High visibility within the field

- Retaining the copyright to your article

Submit your next manuscript at $>$ springeropen.com 